
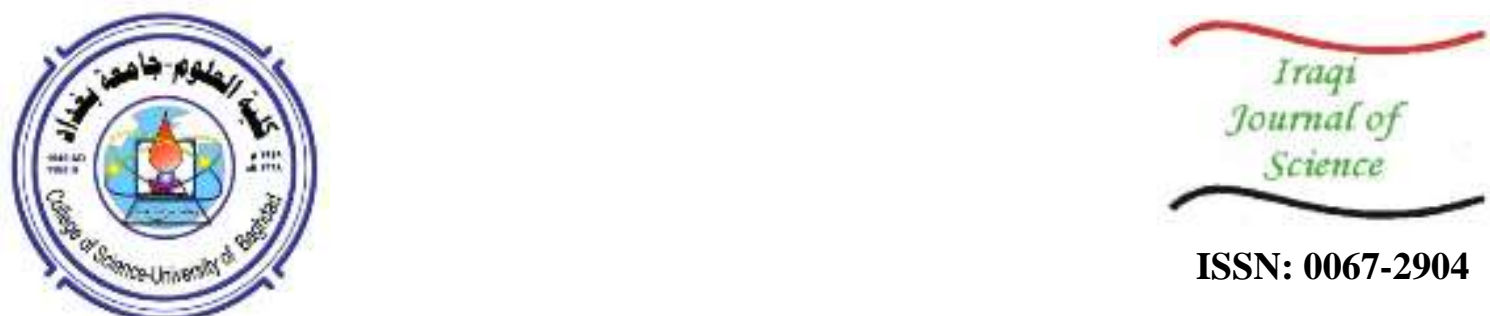

ISSN: 0067-2904

\title{
Morphological and Molecular Identification of Three Genera of the Family Heptageniidae (Ephemeroptera) from Ava Sheen Branch/ Greater Zab Tributary, North of Iraq
}

\author{
Shelan Mustafa Khudhur*, Yahya Ahmed Shekha \\ Department of Environmental Science and Health, College of Science, Salahaddin University-Erbil
}

Received: 26/8/ $2019 \quad$ Accepted: 30/9/2019

\begin{abstract}
The aquatic Heptageniidae family of Ava-sheen branch (Greater Zab Tributary) in Duhok Governorate/ Iraq was studied. Samples were collected using Surber stream sampler to study their diagnostic morphological characteristics and molecular phylogenetic profile using a nuclear gene 16s ribosomal RNA. The morphological and molecular identification supported that the three species, Epeorus longimanus, Heptagenia elegantula and Ephemerella cornutus belong to Heptageniidae family, while the molecular results also confirmed the monophyletic origin of these three genera.
\end{abstract}

Keywords: Molecular, morphology, Heptageniidae and Iraq.

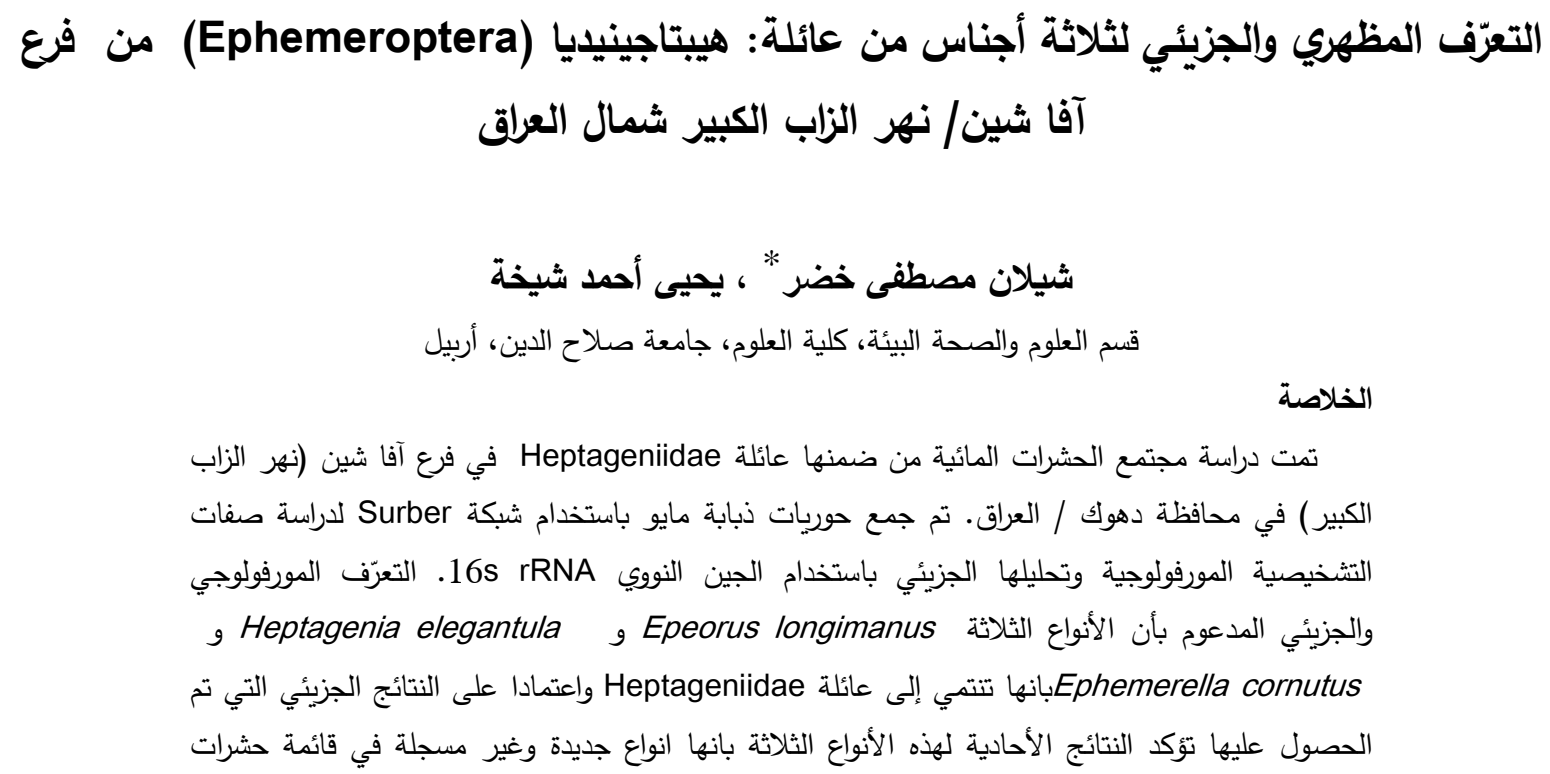

العراقية.

\section{Introduction}

Aquatic insects are among the most commonly used benthic macroinvertebrates which, as part of their life stages, are linked with an aquatic or semi-aquatic environment and have an important role in the functioning of the ecosystem, nutrient cycling, primary production, decomposition and translocation of materials [1,2]. These organisms can also be used as bio-indicators for freshwater monitoring[3]. The physical, chemical and biological characteristics of the river affect aquatic insects

*Email: shelan.khudhur@su.edu.krd 
because each has distinct environmental tolerance values where only few species can survive in polluted ecosystems $[4,5]$.

Mayflies constitute an insect group that make up the Ephemeroptera order [6] and play a significant role in nearly all undisturbed freshwater populations [7]. They also function as key taxonomic insects for biomonitoring of water bodies and form an essential part of standardized running water assessment systems [3, 7]. The world's fauna of Ephemeroptera is comprised of 42 families, 400 genera and 3000 species [8]. Heptageniidae is one of the most abundant and significant family that belong to the order Ephemeroptera. Nymphs live as benthic communities in distinct kinds of lotic freshwater habitats such as rivers, streams, lakes, brooks, ponds, and marshes in most parts of the globe, while they can also be found under the rocks, tree trunks, plants, and leaf debris. The distribution of nymphs depends upon water current and substrate type [9]. Many species of heptageniidia were targeted in aquatic research because of their important role in biomonitoring studies of anthropogenic disturbance [10].

It is particularly difficult to identify mayflies at the larval stage on a morphological basis $[10,11]$. Thus, it is often impossible to assign species names in research in which immatures constitute a big percentage of the sample [10]. Recently, many efforts were made to identify species using modern and non-traditional techniques. In most instances, two distinct methods are used, which are DNA taxonomy and contemporary photo processing and classification [11]. DNA barcoding solves this issue by connecting freshly gathered samples to a reference library of authoritative samples [12]. Hence, DNA barcoding in insects has proven to be a fast, reliable and cost-effective strategy for finding new species [3]. This method holds much promise as a tool for taxonomic research and as a basis for phylogenetic analysis and biomonitoring of aquatic ecosystems [13, 14]. Genetic diversity, however, is important in identifying unique populations for conservation purposes. Aspects of DNA barcoding, loss of genetic diversity in cryptic species, and examples of molecular phylogenetic and molecular phylogeographic research of headwaters aquatic insects from significant biogeographic areas are commonly examined in the context of taxa and habitats prioritized for preservation [15].

The Great Zab River catchment is a major left bank tributary of the Tigris River and drains a significant portion of Northern Iraq's Kurdistan Region [16]. There have been a limited number of studies [17- 19] on the faunistic and environmental aspects of aquatic insects in Northern Iraq. The present study intends to help fill this gap by providing an overview of the literature published to date on the aquatic insects of Iraq especially in Kurdistan region. This is the first comprehensive faunistic study of aquatic insects from the county and may provide basic data for further taxonomic and ecological studies of aquatic insects in the north of Iraq. A further aim of this study was to consider the obtained results from the ecological aspect as bio-indicators of Greater Zab Tributary.

\section{Materials and method}

\section{Description of study sites}

In this study, Ava sheen River was selected as site for sampling and collecting of aquatic insects, which is one of the of the Greater Zab Tributary Basin branches that is located about $32 \mathrm{~km}$ south east Amadiya town and about $83 \mathrm{~km}$ north east Duhok Governorate in the north of Iraq (370 $01^{\prime} 05^{\prime \prime} \mathrm{N}, 43^{\circ}$ 50'09" E) (Figure-1).

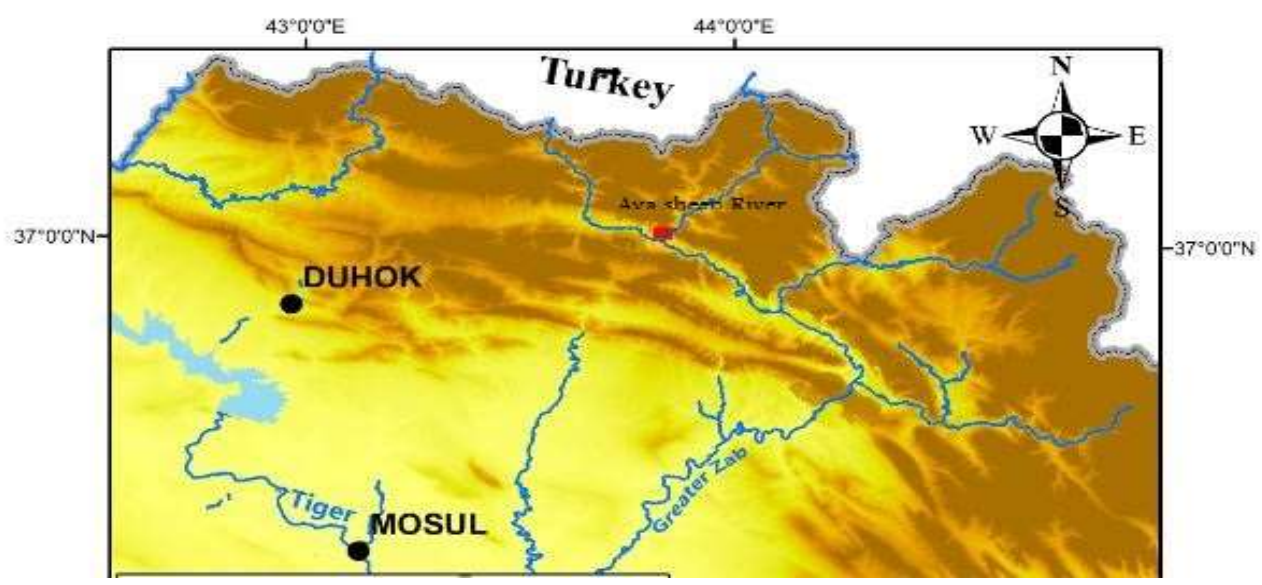

Figure 1- A map of northern Iraq showing the studied site. 


\section{Specimen sampling}

A total of twenty mayfly nymphs were collected by Surber sampler (500 $\mu \mathrm{m}$ mesh) from water as well as sediments, rocks and fallen leaves during three-month period from (October, November and December 2016). Samples were identified with date, place and co-ordinates and first kept in the field in ethyl alcohol. After being transported to the laboratory, benthic macroinvertebrates and insect samples were isolated from the substratum materials, washed with water and then preserved in $95 \%$ ethyl alcohol solution for further studies [20].

\section{Morphological examination}

The morphology and aquatic nymph determination were carried out using the keys and descriptions available, based on taxonomically significant structures for the species such as mouth parts, dorsal surface, posterior margin of terga, denticles on tarsi, tibiae, and femora, in addition to tarsal claws and abdominal gills [21]. Specimens were examined using an Olympus BX51 light microscope equipped with a digital camera.

\section{Molecular evaluation}

After the morphological identification, a total of ten samples (2 replications for each) from the collection site at Sheen River were processed at the Molecular Biology Laboratory of the Department of Biological Sciences of Ankara University (Ankara, Turkey).

Tissue samples from the thorax and abdomen were obtained according to a previously described procedure [22] . Genomic DNA was extracted using the CTAB method [23], following the standard protocol indicated by the manufacturer. DNA quality and quantity were measured using a Nano VueTM Plus spectrophotometer.

PCR amplification was conducted using universal primers. The 16S ribosomal RNA gene was amplified using the primer pair 16Sa (F) 50- GCCTGTTTATCAAAAACAT-30 and 16Sb (R) 50CTCCGGTTTGAACTCAGATCA-30 [24].

The amplifications were performed on a Techne TCPLUS thermocycler according to the following conditions: initial denaturation at $94^{\circ} \mathrm{C}$ for $2 \mathrm{~min}$, followed by 7 cycles at $94^{\circ} \mathrm{C}$ for $30 \mathrm{sec}$., $45^{\circ} \mathrm{C}$ for $30 \mathrm{sec}$, and $72^{\circ} \mathrm{C}$ for $45 \mathrm{sec}$., followed by 28 cycles at $94^{\circ} \mathrm{C}$ for $30 \mathrm{sec} ., 48^{\circ} \mathrm{C}$ for $30 \mathrm{sec}$, and $72^{\circ} \mathrm{C}$ for $45 \mathrm{sec}$., with completing the reaction with a final extension cycle at $72^{\circ} \mathrm{C}$ for 7 min for the $16 \mathrm{~S}$ rRNA gene [22] .

PCR products were tested using agarose gel electrophoresis (Invitrogen). PCR products were purified using the QIA quick PCR purification kit (QIAGEN_), according the manufacturer's instructions, and sequenced at Macrogen Advancing Through Genomics - Netherlands. Sequences obtained were evaluated and edited using the MEGA software.

\section{Data analysis}

The phylogenetic characteristics were evaluated using MVSP software, whereas the forward and reverse sequences were edited and assembled using Sequencher (C) 2011. All the sequences were aligned in MEGA v 6.0.6 [25], using the Clustal W algorithm with default parameters.

\section{Results and Discussion}

The present study's combined molecular and morphological analyses clearly support the assignment of Epeorus longimanus, Heptagenia elegantula and Ephemerella cornutus to Heptageniidae family. The results also demonstrated that the three species have common characteristics such as distinctly flattened body; flattened head; dorsal eyes and antennae; invisible mandibles in dorsal view; much shorter claws than tarsi; and straight tibiae and tarsi (Heptageniidae) [21]. Some species of the Epeorus sp. were identified here depending on the larvae and reared imagos, in line with the taxonomic research of the mayflies [26- 31], whereas Heptagenia sp. was studied by other artticles [31-35] and Ephemerella sp. was described another group of authors [36-39].

Epeorus longimanus (Eaton, 1885)

Figure-2 (A) shows the whole body of E. longimanus which has the following characteristics: Body and head distinctly flattened, gills lateral in position at least on abdominal segments 4 to 6 , lamellae usually broad, gill filaments variable, with only two well developed caudal filaments, gills inserted laterally on segments 2-6, possible extension ventrally on segments 1 and 7, claws without a tooth but with three or more subapical denticles, abdominal tubercles present or absent. Some of these characters were previously described [40]. E. longimanus is usually found in clear and cool streams in areas of moderate to fast flow, particularly on rocks in riffles. This was confirmed by a previous publication [41], which stated that Epeorus longimanus was the most common aquatic invertebrate 
inhabiting the riffles and an intolerant species in the Heptageniidae family which has developed the ability to use their gills to adhere to substrates in rapid currents in the sampled riffle.

Heptagenia elegantula (Eaton, 1885)

There are small differences between Heptagenia species[21, 31]. Some of the diagnostic morphological characteristics are shown in Figure-2 (B), as follows. Brown colour with pale markings present on head, thorax and abdomen; distinctly flattened body and head; dorsal eyes and antennae; front of head entire or only slightly incised medially; pronotum widest at anterior margin; straight or slightly emarginated posterior margin; invisible mandibles in dorsal view; apex of outer incisor of planate mandible; fore femora are usually brown dorsally with pale undulate median band and large basal pale spot, often extending to median band; dorsal surface of each femur is with an oval or paddle - shaped setae; claws without denticles but with a basal tooth; gills lateral in position at least on abdominal segments 4 to 6; lamellae usually broad; gill filaments variable, with three well developed caudal filaments; maxillary palpi rarely protrude at sides of head; gills on segment 7 similar to preceding pairs but smaller; trachea of gill 7 with lateral branches; gill lamellae on segment 1 are twothirds as long as those on segment 2; fibrilliform portion of gill 1 usually subequal to or shorter than lamella; labrum never narrower at apex than at base; a widespread and relatively common genus; can be found year round inconspicuous; in lotic waters and in slow moving waters under stones or debris near banks or in pools. Heptagenia elegantula larvae are found in warmer silted streams [32, 33]

Ephemerella cornutus (Gose, 1980)

Genus diagnosis is shown in Figure-2 (C). The most reliable characteristics for recognizing $E$. cornutus are its large size with specimens larger than $9 \mathrm{~mm}$.; generally, brown in colour; wings smoky in colour [42]; abdominal gills exposed; gills on segment (2-7) variable; long setae absent; gills on segment 2 non operculate; gills absent on abdominal segment 2, absent or rudimentary on segment 1 , present in segment 3; gills on segments 3-7 or 4-7 consist of anterior oval lamellae and posterior lamella with lobes; thorax, head, and abdomen without large paired tubercles; maxillary palps well developed; leading margin of fore femora with tubercles; apical tibial projection usually straight and moderately sharp; tarsal claws with two to two to four denticles; caudal filaments brown; caudal filaments sub-equal in length; caudal filaments with or without whorls of spines at apex of each segment [36, 43, 44]. They inhabit primarily lotic waters, in areas of fast flow in crevasses of hard substrates, but some species are found in vegetation and root mats in edge areas where there is slow flow.

\section{Phylogenetic analysis}

The present study applied the Bayesian phylogenetic reconstruction (Figure-3) which clearly supports the monophylogeny of the Ephemerella but not the Epeorus and Heptagenia species. Epeorus and Heptagenia are form similar monophyletic groups (Gower General Similarity Coefficient=0.679) and the taxonomic integrity of all sampled species within the two genera is also validated. The focal species, Epeorus longimanus and Heptagenia elegantula, clustered together to form a distinct and highly supported monophyletic clade. The Ephemerella cornutus clade is further divided into separate clade. The maximum-likelihood analysis yielded similar topology $(\mathrm{PP}=0.462)$ but with lower support values (indicated on the Gower General Similarity Coefficient).

The analysis of phylogenetic relations between individual Caucasiron lineages would require a broader spectrum of genetic markers [45] and we refrain from making phylogenetic assumptions from our data. They suggested for mayflies in general [10]. Additionally, every species for which we had more than one specimen was strongly supported as monophyletic. The only species pair that showed lower than expected divergence was E. cornutus vs. E. longimanus and H. elegantula. Ephemeroptera was strongly supported as monophyletic. Ephemeroidea constituted a monophyletic group and some of the relationships between the different families were not always strongly supported [46].

\section{Molecular analysis}

The percentage distribution of three insect species BLAST from Gene bank NCBI of partial 16s ribosomal RNA gene is shown in table 1. We found that the sequences of 16s rRNA successfully distinguished between genera and species of E. longimanus, H. elegantula and E. cornutus because intra- and intraspecific sequences differed by at least an order of magnitude in nearly every species comparison. 


\section{Phylogenetic inferences}

Phylogenetic analysis based on ribosomal RNA nucleotide sequence revealed the grouping of the three investigated species of Epeorus longimanus, Ephemerella cornutus and Heptagenia elegantula on expected lines, as shown in Figure-4. From sequence divergence similarity data and the constructed phylogeny, it was revealed that the species belonging to the respective genera were close to each other. The three samples species grouped in three clusters with low distances and high similarity. In the first cluster, Epeorus longimanus is in the same cluster with Epeorus longimanus by Gene bank Accession Number (GAN) AY749757.1, with a distance of 0.08. In the second, Ephemerella cornutus is in the same cluster with Ephemerella cornutus by GAN of FJ443041.1, with a distance of 0.05. In the third cluster, Heptagenia elegantula is in the same cluster with Heptagenia elegantula by GAN of MH456926.1, with a distance of 0.03. All the three species were identified by NCBI nblast.

This result was also supported by several previous studies $[36,44]$ which clarified that some species of Ephemerella have a monophyletic clade. Also, another study [46] supports our result, as it showed that some families such as Heptageniidae, Isonychiidae, Baetidae, Acanthametropodidae, Metretopodidae, Ameletidae and Nesameletidae are monophyletic. It was recently determined that the monophyly of the families Heptageniidae, Baetidae, and Ephemerellidae is highly supported [47]. E. herklotsi is a sister clade to Epeorus sp2. (KJ493406).

It was also endorsed by relatively high genetic distances to other species. Several studies of the DNA barcoding highlighted the cases where this approach was found unsuitable for species identification [29, 48]. However, the results obtained in the studies on mayflies show a close correspondence between the morphologically defined species and the barcode clusters $[10,12,14,33$, 44]. The relatively low interspecific divergences were also previously observed in other genera within mayflies, e.g. Baetisca Walsh, 1862, Caenis Stephens, 1835 [10], and Siphlonurus Eaton, 1868[14]. These results might be explained by the young age of the lineages or may reflect the lower substitution rate in these taxa $[10,49]$. If we assume E. (C.) sinitshenkovae and E. (C.) longimaculatus to be separate species, the intraspecific variation within our dataset ranged between 0.00 and $4.72 \%$ and interspecific between 5.79 and $18.51 \%$. The barcode gap width formed was $1.07 \%$. The previous studies on mayflies showed variable ranges of barcode gap, from much higher values $[33,50]$ to no gap observed $[10,14,44]$. The mean interspecific divergence $(14.33 \%$ with $E$. (C.) sinitshenkovae and $E$. (C.) longimaculatus constrained as separate species) obtained in our results showed similar value to other reported divergences for congeneric species within mayflies [14, 33, 44] or within Heptageniidae in particular [10]. Therefore, our results confirmed the generally high level of $16 \mathrm{~s}$ rRNA sequence divergence within Ephemeroptera [14].
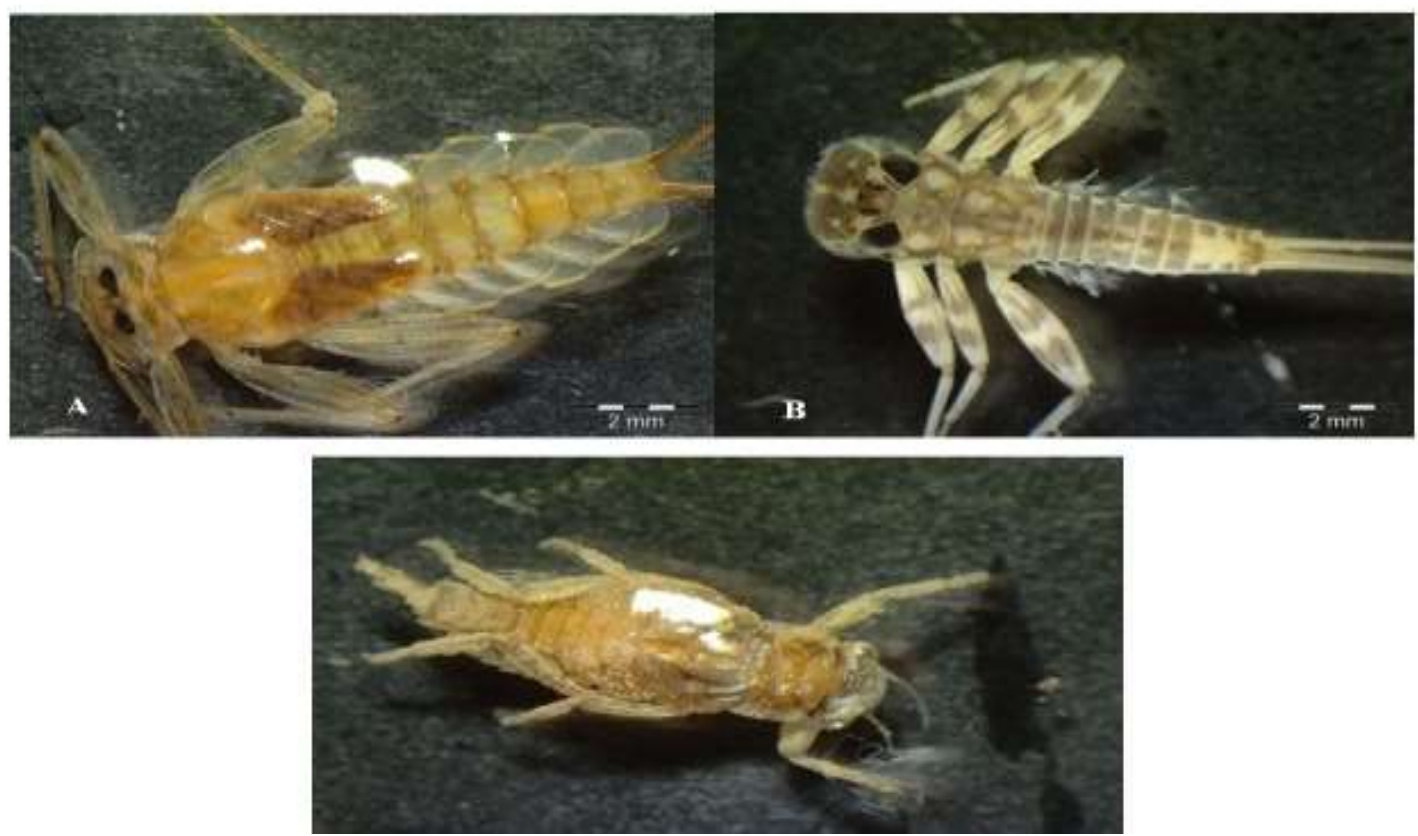

Figure 2- Whole body of the three studied genera, (A) Epeorus longimanus; (B) Heptagenia elegantula; (C) Ephemerella cornutus 
Table 1-Percentage distribution of three samples insect species blast from Gene bank NCBI of partial 16s ribosomal RNA gene

\begin{tabular}{cccccc}
\hline $\begin{array}{c}\text { Insect } \\
\text { Sample } \\
\text { s }\end{array}$ & $\begin{array}{c}\text { Query } \\
\text { Cover } \\
\mathbf{\%}\end{array}$ & $\begin{array}{c}\text { Identic } \\
\text { Number } \%\end{array}$ & $\begin{array}{c}\text { Genebank } \\
\text { Accession } \\
\text { Number }\end{array}$ & $\begin{array}{c}\text { Genebank Insect Species } \\
\text { Identification }\end{array}$ & $\begin{array}{c}\text { Country } \\
\text { Identification }\end{array}$ \\
\hline $\mathbf{1}$ & $99 \%$ & $87.68 \%$ & AY749757.1 & Epeorus longimanus & USA \\
\hline $\mathbf{2}$ & $100 \%$ & $100 \%$ & FJ443041.1 & Ephemerella cornutus & USA \\
\hline $\mathbf{3}$ & $100 \%$ & $100 \%$ & MH456926.1 & Heptagenia elegantula & USA \\
\hline
\end{tabular}

UPGMA
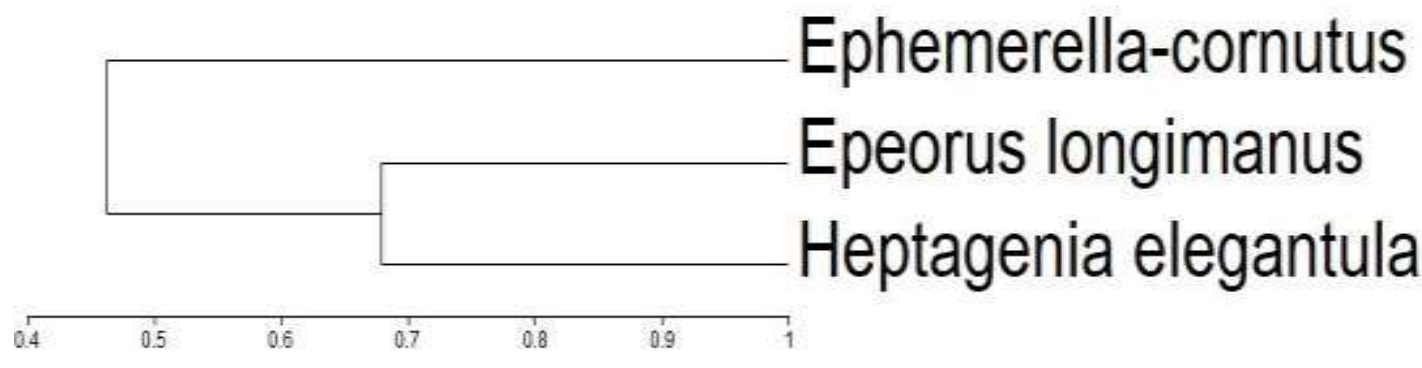

Gower General Similarity Coeffoient.

Figure 3-Dendrogram of morphological characters of the three Heptageniidae species
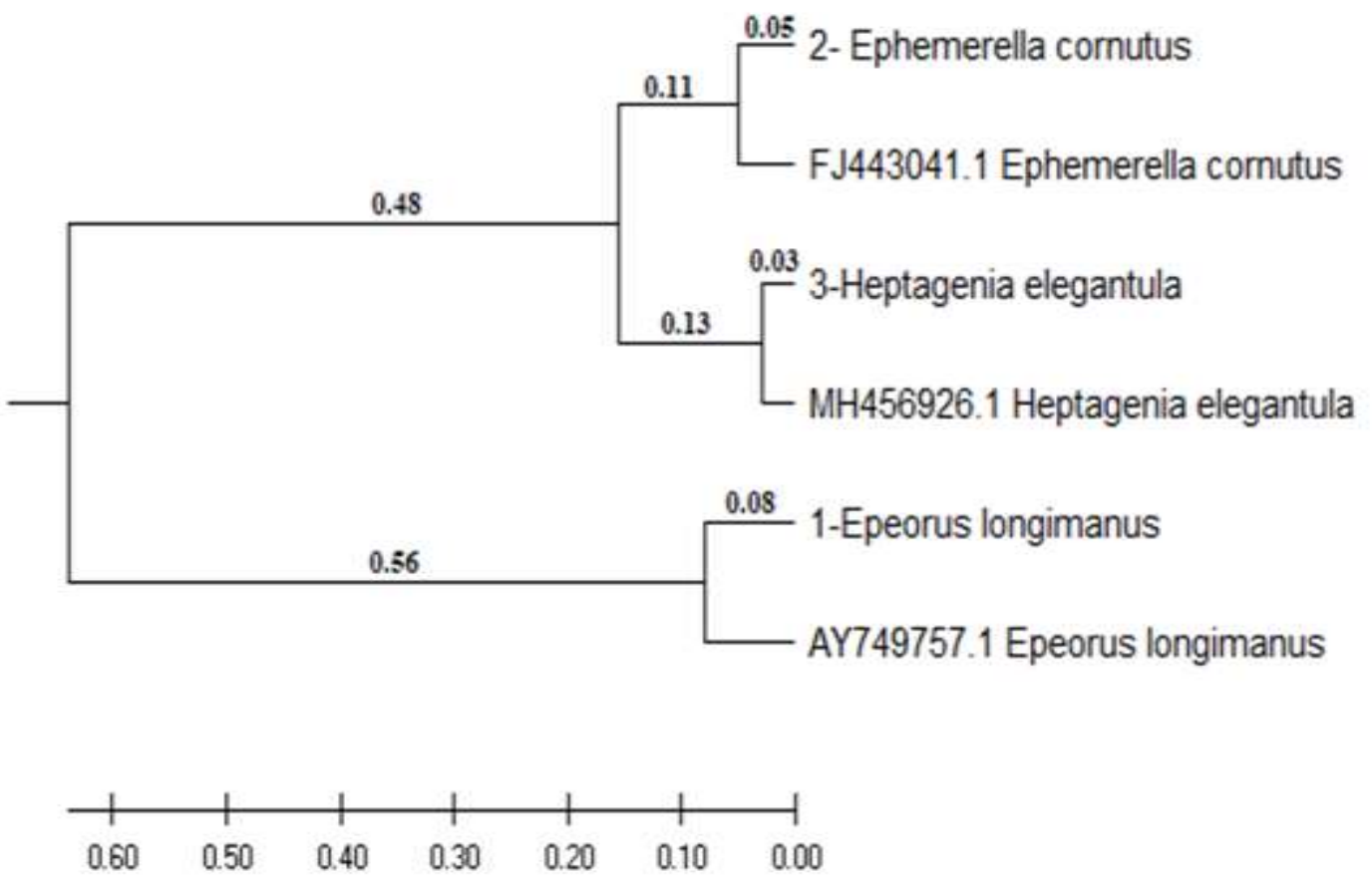

Figure 4-Mega $X$ program showing phylogenetic positioning and identification of the three difference species of Epeorus longimanus, Heptagenia elegantula and Ephemerella cornutus according to partial sequences of ribosomal RNA gene, 1-Epeorus longimanus, 2-Ephemerella cornutus and 3-Heptagenia elegantula. 


\section{References}

1. AzmI, W.A.; Hussin, N.H. and Amin, N. M. 2018. Monitoring Of Water Quality Using Aquatic Insects As Biological Indicators In Three Streams Of Terengganu. Journal of Sustainability Science and Management. 13(1): 67-76.

2. Shaeghi, M.; Dehghan, H.; Pakdad,K.; Nikpour,F.; Absavaran, A.; Sofizadeh, A.; Akhavan, A. A.; Vatandoost, H. and Aghai-Afshar, A. 2017.Faunistic study of the aquatic arthropods in a tourism area in northern Iran. Journal of arthropod-borne diseases. 11(2): 286.

3. Cardoni, S.; Tenchini, R.; Ficulle, I.; Piredda, R.; Simeone, M. C.; Belfiore, C. 2015. DNA barcode assessment of Mediterranean mayflies (Ephemeroptera), benchmark data for a regional reference library for rapid biomonitoring of freshwaters. Biochemical Systematics and Ecology. 62: $36-50$.

4. Priawandiputra, W.; Zakaria, F. and Prawasti, T. 2018. Aquatic Insect Community as Indicator of Water Quality Assessment in Situ Gede System, Bogor, Indonesia. in IOP Conference Series: Earth and Environmental Science. IOP Publishing.

5. Labajo-Villantes, Y.I. and Nuñeza, O.M. 2015. Macroinvertebrates as bioindicators of water quality in Labo and Clarin rivers, Misamis Occidental, Philippines. International Journal of Biosciences. 6 (9): 62-73.

6. Jacobus, L.M., Macadam, C.R. and Sartori, M. 2019. Mayflies (Ephemeroptera) and Their Contributions to Ecosystem Services. Insects. 10(6): 170.

7. Bauernfeind, E. and Moog, O. 2000. Mayflies (Insecta: Ephemeroptera) and the assessment of ecological integrity: a methodological approach, in Assessing the Ecological Integrity of Running Waters. Springer. p. 71-83.

8. Rutschmann, S.; Detering, H.; Simon, S.; Funk, D. H.; Gattolliat, J.-L.; Hughes, S. J.; Raposeiro, P. M., DeSalle, R., Sartori, M. and Monaghan, M. T. 2017. Colonization and diversification of aquatic insects on three Macaronesian archipelagos using 59 nuclear loci derived from a draft genome. Molecular phylogenetics and evolution. 107: 27-38.

9. Webb, J. and McCafferty, W. 2011.Contributions to the larvae of North American Nixe (Ephemeroptera: Heptageniidae), with the description of $\mathrm{N}$. dorothae sp. nov. from southern Indiana. Zootaxa. 3065(1): 27-37.

10. Ball, S.L., Hebert, P.D.N., Burian, S. K. and Webb, J.M. 2005. Biological identifications of mayflies (Ephemeroptera) using DNA barcodes. Journal of the North American Benthological Society. 24(3): 508-524.

11. Polášek, M., Godunko, R. J., Rutschmann, S., Svitok, M., Novikmec, M. and Zahrádková, S. 2018. Integrative taxonomy of genus Electrogena (Ephemero ptera: Heptageniidae): the role of innovative morphological analyses for species delimitation. Arthropod Systematics \& Phylogeny. 76(3): 449-462.

12. Zhou, X., Jacobus, L. M., Edward DeWalt, R., Adamowicz, S. J. and Hebert, P. D.N. 2010. Ephemeroptera, Plecoptera, and Trichoptera fauna of Churchill (Manitoba, Canada): insights into biodiversity patterns from DNA barcoding. Journal of the North American Benthological Society. 29(3): 814-837.

13. Suh, K.I., Hwang, J. M., Bae, Y. J. and Kang, J. H. 2019.Comprehensive DNA barcodes for species identification and discovery of cryptic diversity in mayfly larvae from South Korea: Implications for freshwater ecosystem biomonitoring. Entomological Research. 49(1): 46-54.

14. Webb, J.M., Jacobus, L. M., Funk, D. H., Zhou, X., Kondratieff, B., Geraci, Ch. J., DeWalt, R. E., Baird, D. J., Richard, B., Phillips, I. and Hebert, P. D.N. 2012. A DNA barcode library for North American Ephemeroptera: progress and prospects. 7(5): e38063.

15. Sivaramakrishnan, K.; Janarthanan Sundaram, J.; Selvakumar Chellappa, S. and Muthusamy Arumugam, M. 2014. Aquatic insect conservation: a molecular genetic approach. Conservation genetics resources. 6(4): 849-855.

16. Ismaiel, I.A., Bird, G., McDonald, M. A., Perkins, W.T. and Jones, T.G. 2018. Establishment of background water quality conditions in the Great Zab River catchment: influence of geogenic and anthropogenic controls on developing a baseline for water quality assessment and resource management. Environmental earth sciences. 77(2): 50.

17. Ali, L. 2006. A study of macroinvertebrates community in the middle sector of Greater Zab River, Iraq. Ph. D. Thesis. Univ. of Baghdad. Iraq. 
18. Hanna, N.S. 2015. Using Aquatic Insects as Bioindicators in Water Quality Assessment of Bekhal (Maran), Zar Gali and Khalan Streams. Salahaddin University-: Erbil. p. 141.

19. Shekha, Y.A. 2011. A Study of Benthic Macroinvertebrate Community in the Lower Part of Greater Zab River Near Guwer Subdistrict. Rafidain journal of science. 22(1E): 33-45.

20. Molina, C.I., Gibon, F.M., Dominguez, E., Pape, T. and Rønsted, N. 2017.Associating immatures and adults of aquatic insects using DNA barcoding in high Andean streams. Ecología en Bolivia. 52(2): 88-99

21. Merritt, R., Cummins, K. and Berg, M. 2008. An introduction to the aquatic insects of North America, 4th edn. Kendall. Hunt Publishing Company, Dubuque.

22. Ossa-López, P.A.,. Camargo-Mathias, M.I. and Rivera-Páez, F.A. 2018. Andesiops peruvianus (Ephemeroptera: Baetidae): a species complex based on molecular markers and morphology. Hydrobiologia. 805 (1): 351-364.

23. Sambrook, J., Fritsch, E.F.and Maniatis, T. 2001. Molecular cloning: a laboratory manual. Cold spring harbor laboratory press.

24. Ogden, T.H. and Whiting, M.F. 2005. Phylogeny of Ephemeroptera (mayflies) based on molecular evidence. Molecular phylogenetics and evolution. 37(3): 625-643.

25. Tamura, K., Stecher, G., Peterson, D., Filipski, A. and Kumar, S. 2013. MEGA6: molecular evolutionary genetics analysis version 6.0. Molecular biology and evolution. 30(12): 2725-2729.

26. Zurwerra, A., Tomka, I. and Lampel, G. 1986. Morphological and enzyme electrophoretic studies on the relationships of the European Epeorus species (Ephemeroptera, Heptageniidae). Systematic Entomology. 11(2): 255-266.

27. Bae, Y. J. 2004. Larvae of the Heptageni id Mayfly Genus Epeorus (Ephemeroptera'-Heptageni idae) from Vietnam. Journal of Asia-Pacific Entomology. 7(1): 19-28.

28. Sivaramakrishnan, K. 2013. Epeorus petersi, a new species of Heptageniidae (Ephemeroptera) from the Western Ghats of southern India. Zootaxa. 3731(3): 391-394.

29. Hrivniak, L., Sroka, P., TÜrkmen, G., Godunko, R. J. and Kazanci, N. 2019. A new Epeorus (Caucasiron)(Ephemeroptera: Heptageniidae) species from Turkey based on molecular and morphological evidence. Zootaxa. 4550(1): 58-70.

30. Webb, J. and McCafferty, W. 2006. Contribution to the taxonomy of Eastern North American Epeorus Eaton (Ephemeroptera: Heptageniidae). Zootaxa. 1128(1): 57-64.

31. Webb, J. and McCafferty, W. 2008. Heptageniidae of the world, Part II: key of the genera. Canadian Journal of Arthropod Identification. 7: 1-55

32. Andrew, F.B. 1980.Mountain Region (Ephemeroptera: Heptageniidae). Pan-Pacific Entomologist. 56(1): 51-62.

33. Webb, J. 2007.A new species and new synonym in Heptagenia Walsh (Ephemeroptera: Heptageniidae: Heptageniinae) based on molecular and morphological evidence. Journal of Insect Science, 7(1).

34. Bright, E. 2017. Aquatic insects of Michigan. Aquatic Insects of Michigan.

35. Rana, J.S., Semalty, B., Singh, P., Swami, N., Dewan, S., Singh, J., Gusain, M.P. and Gusain, O. P. 2019. checklist of benthic macroinvertebrate taxa along different riparian land use types in Alaknanda River Catchment of the Central Himalaya, Uttarakhand (India). in Proceedings of the Zoological Society. Springer.

36. Ogden, T.H.,Osborne, J. T., Jacobus, L. M. and Whiting, M. F. 2009. Combined molecular and morphological phylogeny of Ephemerellinae (Ephemerellidae: Ephemeroptera), with remarks about classification. Zootaxa. 1991: 28-42.

37. Jacobus, L.M. and McCafferty, W. 2008. Revision of Ephemerellidae genera (Ephemeroptera). Transactions of the American Entomological Society. 134(1): 185-275.

38. Koss, R.W. 2017. A list of the mayflies (Ephemeroptera) in the Michigan State University Entomology Museum. The Great Lakes Entomologist. 3(4): 1.

39. Shapas, T.J. and Hilsenhoff, W.L. 2017. Feeding habits of Wisconsin's predominant lotic Plecoptera, Ephemeroptera, and Trichoptera. The Great Lakes Entomologist. 9(4): 3.

40. Edmunds, G.F. and Allen, R.K. 1964.The rocky mountain species of Epeorus (Iron) Eaton (Ephemeroptera: heptageniidae). Journal of the Kansas Entomological Society. 37(4): 275-288.

41. Voshell, J.R. 2002. A guide to common freshwater invertebrates of North America. Nature. p. 442. 
42. Steger, A.L. 1931.Some preliminary notes on the genus Ephemerella. Psyche: A Journal of Entomology. 38(1): 27-35.

43. Allen, R.K. and Edmunds, G.F. 1962. A Revision of the Genus Ephemerella (Ephemeroptera, Ephemerellidae) V.: The Subgenus Drunella in North America.: Entomological Society of America.

44. Alexander, L.C., Delion, M., Hawthorne, D. J., Lamp, W. O. and Funk, D. H. 2009. Mitochondrial lineages and DNA barcoding of closely related species in the mayfly genus Ephemerella (Ephemeroptera: Ephemerellidae). Journal of the North American Benthological Society. 28(3): 584-595.

45. DeSalle, R., Egan, M.G. and Siddall, M. 2005.The unholy trinity: taxonomy, species delimitation and DNA barcoding. Philosophical Transactions of the Royal Society B: Biological Sciences. 360 (1462): 1905-1916.

46. Ogden, T.H., Gattolliat, J. L., Sartori, M., Staniczek, A.H., Soldán, V. and Whiting, M.F. 2009. Towards a new paradigm in mayfly phylogeny (Ephemeroptera): combined analysis of morphological and molecular data. Systematic Entomology. 34(4): 616-634.

47. $\mathrm{Wu}, \mathrm{M} .-\mathrm{J}$. and $\mathrm{Yu}, \mathrm{L} . \mathrm{-L}$. 2018. The complete mitochondrial genome of Epeorus herklotsi (Ephemeroptera: Heptageniidae) and its phylogeny. Mitochondrial DNA Part B. 3(1): 303-304.

48. Meier, R., Shiyang, K., Vaidya, G. and PK, N. 2006. DNA barcoding and taxonomy in Diptera: a tale of high intraspecific variability and low identification success. Systematic biology. 55(5): 715-728.

49. DeWalt, R.E. 2011. DNA barcoding: a taxonomic point of view. Journal of the North American Benthological Society. 30(1): 174-181.

50. Kjærstad, G., Webb, J.M. and Ekrem, T. 2012. A review of the Ephemeroptera of FinnmarkDNA barcodes identify Holarctic relations. Norwegian Journal of Entomology. 59(2): 182-195. 